\title{
Antioxidant Activity of Ethanol Extract of Turmeric Rhizome (Curcuma domestica Val), Trengguli Bark (Cassia fistula L), and Its Combination with DPPH Method
}

\author{
Triyono Triyono*, Anis Y. Chaerunisaa, Anas Subarnas
}

Department of Pharmaceutical Technology, Faculty of Pharmacy, Universitas Padjadjaran, Jawa Barat - Indonesia

Submitted 11 December 2017; Revised 20 December 2017; Accepted 16 February 2018, Published 27 June 2018

*Corresponding author: triyonoapt@gmail.com

\begin{abstract}
Turmeric rhizome (Curcuma domestica Val) and Trengguli bark (Cassia fistula $\mathrm{L}$ ) contain antioxidant compounds which can be determined by 1,1-Diphenyl-2-Pycrylhydrazyl (DPPH) free radical inhibition method. This research was conducted to determine DPPH free radical inhibition by ethanol extract of turmeric rhizome, the ethanol extract of trengguli bark, and a combination of turmeric rhizome extract - trengguli bark extract (1:1.5) with ascorbic acid as a comparison. Identification of secondary metabolite classes is performed by phytochemical screening. Antioxidant activity was performed by inhibition of free radical color of DPPH using UV-Vis spectrophotometry. The study showed IC ${ }_{50}$ value of ascorbic acid, as a comparison, is $3.14 \mu \mathrm{g} / \mathrm{mL}$. While ethanol extract of trengguli bark has the best antioxidant activity with $\mathrm{IC}_{50}$ value $10.98 \mu \mathrm{g} / \mathrm{mL}$ compare to combination ethanol extract of turmeric rhizome - trengguli bark $(1: 1.5)$ and ethanol extract of turmeric rhizome with $\mathrm{IC}_{50}$ value is $13.70 \mu \mathrm{g} /$ $\mathrm{mL}$ and $41.95 \mu \mathrm{g} / \mathrm{mL}$, respectively.
\end{abstract}

Keywords: Antioxidant, Cassia fistula, Curcuma domestica, DPPH Method.

\section{Aktivitas Antioksidan Ekstrak Etanol Rimpang Kunyit (Curcuma domestica Val), Ekstrak Etanol Kulit Batang Trengguli (Cassia fistula L) dan Kombinasinya dengan metode DPPH}

\begin{abstract}
Abstrak
Rimpang Kunyit (Curcuma domestica Val) dan Kulit batang trengguli (Cassia fistula L) mengandung senyawa yang bersifat antioksidan yang dapat ditentukan dengan metode peredaman radikal bebas 1,1-Difenil-2- pikrilhidrazil (DPPH). Penelitian ini dilakukan untuk mengetahui peredaman radikal bebas DPPH oleh ekstrak etanol rimpang kunyit, ekstrak etanol kulit batang trengguli, kombinasi ekstrak rimpang kunyit - ekstrak kulit batang trengguli (1 : 1.5) dengan asam askorbat sebagai pembanding. Metode skrining fitokimia dilakukan untuk mengidentifikasi metabolit sekunder pada ekstrak. Pengujian aktivitas antioksidan dilakukan dengan metode DPPH yang dianalisa menggunakan spektrofotometri UV-Vis. Penelitian ini menunjukkan nilai IC $_{50}$ asam askorbat, sebagai perbandingan, adalah $3.14 \mu \mathrm{g} / \mathrm{mL}$. Sedangkan ekstrak etanol kulit batang trengguli memiliki aktivitas antioksidan dengan nilai $\mathrm{IC}_{50} 10,98 \mu \mathrm{g} / \mathrm{mL}$ paling baik daripada kombinasi ekstrak etanol rimpang kunyit ekstrak etanol kulit batang trengguli (1: 1.5) dan ekstrak etanol rimpang kunyit yang memiliki nilai IC 50 sebesar $13.70 \mu \mathrm{g} / \mathrm{mL}$ dan $41.95 \mu \mathrm{g} / \mathrm{mL}$.
\end{abstract}

Kata Kunci: Antioksidan, Cassia fistula, Curcuma domestica, metode DPPH 


\section{Introduction}

There has been the attention toward the field of free radical chemistry in recent year. Free radicals such as reactive oxygen species and reactive nitrogen species are generated by our body by various endogenous systems, exposure to different pathological states or physiochemical conditions ${ }^{1}$. Free radicals generally form naturally as part of our body's metabolic processes. However, free radicals can also be affected by environmental factors pesticide use in food including, smoking habits, radiation, and pollution ${ }^{2}$. Free radicals are molecules that have one or more unstable electron ${ }^{3}$. Research on antioxidant activity is conducted for the purpose of improvement of food quality and treatment.

Antioxidants have the ability to neutralize free radicals without becoming free radicals themselves ${ }^{4}$. When antioxidants neutralize free radicals by receiving or donating electrons, they will not turn into free radicals and remain stable. Antioxidants are widely found in vegetables, fruits, and medicinal plants 5 .

The use of natural product as traditional medicine is not enough only based on experience passed down from generation to generation, but also need to be proven scientifically. As we known medicinal plants contain active substances that can be efficacious for the cure of disease. Various studies have been conducted to prove the pharmacological activity and determine the chemical content of the natural materials. One of these natural materials has been reported some pharmacological activity is Cassia fistula L. ${ }^{6}$ and Curcuma domestica Val. ${ }^{7}$.

Trengguli plant is proven to have some pharmacological activity. Trengguli bark ethanol extract has antioxidant activity by inhibiting $\mathrm{DPPH}^{8,9}$. Trengguli plant studies show strong relation between hepatoprotective activity and antioxidant activity that can be seen from liver biochemical and oxidative stress parameters ${ }^{10}$. Meanwhile, the study of turmeric rhizome shows that the ethanol extract of turmeric rhizome has hepatoprotective activity in paracetamolinduced rats ${ }^{11}$. Curcumin as one of the active compound in turmeric rhizome has activity as antioxidant, anti-inflammatory, antidiabetic, anticarcinogenic, anticoagulant, antihypertensive, and antidislipidemia ${ }^{12}$. Research on the effectiveness of $C$. domestica Val. as hepatoprotectors and immunomodulators show that turmeric can decrease Serum Glutamic Oxaloacetic Transaminase (SGOT) and Serum Glutamic Pyruvic Transaminase (SGPT) levels and may increase the activity of nonspecific immune systems in mice induced by $\mathrm{CCl}_{4}{ }^{8}$. Other studies have shown that turmeric rhizome has hepatoprotective activity and prevent the increase of SGOT or SGPT due to toxic dosage of acetaminophen ${ }^{13}$.

Various studies abovehave demonstrated various pharmacological activities from turmeric rhizome and different parts of the trengguli plant. The aim of this research is to know the potency of in vitro antioxidant activity on combination of ethanol extract from turmeric rhizome and trengguli bark compare to each extract and ascorbic acid as standard with DPPH method because of its accuracy and ease.

\section{Materials and Methods}

2.1. Material and Apparatus

Turmeric rhizome from species C. domestica Val. and trengguli bark from species $C$. fistula $\mathrm{L}$. obtained from Manoko plantation, Lembang, Bandung. Determination of plants is evaluated at the Laboratory of Taxonomy, Department of Biology, Faculty of Mathematics and Natural Sciences, Padjadjaran University. The chemicals used in this study include ethanol 70\% (Merck), ethano1 96\% p.a (Merck), DPPH (2,2-diphenyl-1-pycryl-hydrazil) (Sigma), ascorbic acid (Merck). Absorbance of sample is analyzed using UV-Vis spectrophotometer (TECAN M200Pro).

\subsection{Method}

\subsubsection{Extraction}

The extraction simplicia of turmeric rhizomes and simplicia of trengguli bark plant were done on different maserator by maceration with $70 \%$ ethanol solvent for 3 
times 24 hours. Liquid extract concentrated with a rotary evaporator at a temperature of $60{ }^{\circ} \mathrm{C}$ then steamed above a water bath with a temperature of $40{ }^{\circ} \mathrm{C}$ until constant weight of the extract. The yield of the extract can be calculated by the formula:

Rendement (\%) $=\frac{\text { Weight of Extract }}{\text { Weight of Simplicia }} \times 100 \%$

Furthermore, the examination of organoleptic extract consisting of form, color, odor, and taste extract.

\subsubsection{Thin Layer Chromatography Patterns}

Thin layer chromatography was performed to determine the chemical content in the extract. In the thin layer chromatography analysis, silica gel phase $\mathrm{GF}_{254}$ was used in this experiment with mobile phase toluene : ethyl acetate : formic acid (5:4:1) for trengguli bark extract ${ }^{8}$ and chloroform : methanol (95: 5) for turmeric rhizome extract. The extract was first dissolved in ethanol and then applied to a silica gel plate of size $10 \mathrm{~cm} \mathrm{x}$ $2.0 \mathrm{~cm}$ and inserted into a chromatographic vessel previously saturated mobile phase. The chromatographic process was stopped when the mobile phase reached the finish line. The chromatogram pattern observed with visible and UV light ( $\lambda 254$ and $\lambda 366 \mathrm{~nm})$, then calculated the value of $\mathrm{Rf}$.

\subsubsection{Determination of $\mathrm{IC}_{50}$ with $\mathrm{DPPH}$ Method}

The ethanol extract of turmeric rhizome, trengguli bark and a combination of ethanol extract of turmeric rhizome - trengguli bark (1:1.5) were added $1 \mathrm{~mL}$ DPPH for each concentration, then vortex and incubated for 30 minutes at room temperature. The absorbance was measured at $516 \mathrm{~nm}$. The inhibition percentage was calculated using the equation :

$$
\% \text { Inhibition }=\frac{\mathrm{Ab}-\mathrm{As}}{\mathrm{Ab}} \times 100 \%
$$

Note :

$\mathrm{Ab}=\mathrm{DPPH}$ absorbance

As $=$ Sample Absorbance
The $\%$ inhibition obtained then used for determined $\mathrm{IC}_{50}$ that showed the concentration of sample to inhibit $50 \%$ free radical

\subsubsection{In vitro Antioxidant Activity Test of} Extract

\section{a. Sample Preparation}

$0.01 \% \mathrm{w} / \mathrm{v}$ ethanol extracts were prepared with a stock solution of 100 ppm. 100 ppm stock solution is diluted to concentration $4,6,12,16,20 \mathrm{ppm}$.

\section{b. Preparation of Comparative Solutions} $0.01 \% \mathrm{w} / \mathrm{v}$ Ascorbic acid was prepared with a solution of $100 \mathrm{ppm}$. Diluted a stock solution untill concentration $10 \mathrm{ppm} .10 \mathrm{ppm}$ stock solution made standard solution 1, 2, 3, 4, 5 ppm.

\section{c. Preparation of DPPH solution (2,2-diphenyl-1-pycryl-hydrazyl)}

DPPH was weighed and dissolved in ethanol p.a at a concentration of $0.01 \% \mathrm{w} / \mathrm{v}$ (100 ppm) for immediate use and maintained in low temperatures and protected from light exposure.

\section{d. Maximum Wavelength Determination}

DPPH solution of $1 \mathrm{~mL}$ was dissolved with ethanol to $5 \mathrm{~mL}$ in 5 -ml flask, measured at $500-530 \mathrm{~nm}$ wavelength to obtain an absorbance of $\pm 0.2-0.8$.

\section{Results}

3.1. Determination

The results of plant determination show turmeric rhizome belongs to the Family: Zingiberaceae, Genus: Curcuma, Species: Curcuma domestica Valeton. Trengguli bark included in the Family: Fabaceae, Genus: Cassia, Species: Cassia fistula L.

\subsection{Extraction}

Turmeric rhizome extraction (1100 g) was macerated with $70 \%$ ethanol solvent resulting rhizome extract of $250.25 \mathrm{~g}$ (rendement $=22.75 \%$ ). While the extraction of trengguli bark (850 g) in maceration with $70 \%$ ethanol solvent resulting trengguli bark extract of $276.25 \mathrm{~g}$ (rendement $=32.50 \%$ ). 
Table 1. Phytochemical Screening Results of Ethanol Extracts of Turmeric Rhizome (EETR) and Ethanol Extract of Trengguli Bark (EETB)

\begin{tabular}{lcc}
\hline \multicolumn{1}{c}{ Parameter } & EETR & EETB \\
\hline Alkaloid & - & - \\
Tanin & - & + \\
Poliphenolic & + & + \\
Saponin & - & + \\
Flavonoid & + & + \\
Monoterpenoid \& Sesqiterpenoid & $+/+$ & $+/+$ \\
Steroid & - & - \\
Triterpenoid & + & + \\
Quinone & + & + \\
\hline
\end{tabular}

3.3. Phytochemical Extract Screening and Organoleptic Test Results

The results of phytochemical screening of extract can be seen in Table 1 and organoleptic test can be seen in Table 2 .

\subsection{TLC results}

TLC results seen in visible light, UV $\lambda 254 \mathrm{~nm}$ and UV $\lambda 366 \mathrm{~nm}$ TLC results can be seen in Table 3.

\subsection{Antioxidant Activity Test Results}

The results of in vitro antioxidant activity test of ethanol extract of turmeric
Table 2. Result of Organoleptic Test from Extract

\begin{tabular}{lcc}
\hline Parameter & EETR & EETB \\
\hline Form & Viscous Liquid & Viscous Liquid \\
Odor & Specific for & Specific for \\
& Turmeric & Trengguli Bark \\
& Rhizome & \\
Color & Brown & Dark Brown \\
Taste & Bitter & Bitter \\
\hline
\end{tabular}

Table 3. Result of TLC Patterns

\begin{tabular}{lcccc}
\hline \multirow{2}{*}{ Sample } & \multirow{2}{*}{ Spot } & \multicolumn{3}{c}{$\mathrm{Rf}$} \\
\cline { 3 - 5 } & & Visible & $\lambda 254$ & $\lambda 366$ \\
\hline \multirow{3}{*}{ EETR } & 1 (Yellow) & 0.30 & 0.31 & 0.31 \\
& 2 (Yellow) & 0.51 & 0.51 & 0.50 \\
& 3 (Yellow) & 0.74 & 0.75 & 0.70 \\
EETB & 1 (Blue) & - & 0.66 & - \\
\hline
\end{tabular}

rhizome, ethanol extract of trengguli bark, combination both of them and ascorbic acid can be seen in Table 4 - 7. For comparasion, ascorbic acid used because known as a strong antioxidant.

\section{Discussion}

Turmeric rhizome ethanol extract from several studies with the DPPH method exhibited strong antioxidant activity. In that studies obtained data $\mathrm{IC}_{50}$ were $73.31 \mu \mathrm{g} /$ $\mathrm{mL} 14$ and $24 \mu \mathrm{g} / \mathrm{mL}^{15}$. In this study value $\mathrm{IC}_{50}$ of ethanol extract turmeric rhizome is 41.95 $\mu \mathrm{g} / \mathrm{mL}$ (Table 5). The value of $\mathrm{IC}_{50}$ ethanol

Table 4. Result of Ethanol Extract of Trengguli Bark Antioxidant Activity

\begin{tabular}{ccccc}
\hline Concentration $(\mathrm{ppm})$ & Absorbance & \% Inhibition & Regression & $\mathrm{IC}_{50}$ \\
\hline 0 & 0.8845 & 0.00 & & \\
4 & 0.6922 & 21.74 & & \\
8 & 0.4968 & 43.83 & $\mathrm{y}=3.5641 \mathrm{x}+10.8886$ & $10.98 \mu \mathrm{g} / \mathrm{ml}$ \\
12 & 0.4168 & 52.87 & & \\
16 & 0.2670 & 69.81 & & \\
20 & 0.1766 & 80.03 & & \\
\hline
\end{tabular}

*Result from triplo sample test ; *Absorbance Control is 0,8845

Table 5. Result of Ethanol Extract of Turmeric Rhizome Antioxidant Activity

\begin{tabular}{ccccc}
\hline Concentration $(\mathrm{ppm})$ & Absorbance & \% Inhibition & Regression & $\mathrm{IC}_{50}$ \\
\hline 0 & 0.8845 & 0.00 & & \\
4 & 0.8528 & 3.58 & & \\
8 & 0.8082 & 8.63 & $\mathrm{y}=1.2193 \mathrm{x}-1.1419$ & $41.95 \mu \mathrm{g} / \mathrm{ml}$ \\
12 & 0.7628 & 13.76 & & \\
16 & 0.7218 & 18.39 & & \\
20 & 0.6803 & 23.09 & & \\
\hline
\end{tabular}

*Result from triplo sample test ; *Absorbance Control is 0,8845 
Table 6. Result of Combination of Turmeric Rhizome Ethanol Extract and Trengguli Bark Ethanol Extract $(1: 1,5)$ Antioxidant Activity

\begin{tabular}{ccccc}
\hline Concentration $(\mathrm{ppm})$ & Absorbance & \% Inhibition & Regression & $\mathrm{IC}_{50}$ \\
\hline 0 & 0.8845 & 0.00 & & \\
4 & 0.7665 & 13.34 & & $13.70 \mu \mathrm{g} /$ \\
8 & 0.6091 & 31.14 & $\mathrm{y}=3.5562 \mathrm{x}+1.2934$ & $\mathrm{ml}$ \\
12 & 0.4806 & 45.66 & & \\
16 & 0.3597 & 59.33 & & \\
20 & 0.2621 & 70.37 & & \\
\hline
\end{tabular}

*Result from triplo sample test ; *Absorbance Control is 0,8845

Table 7. Result of Ascorbic Acid Antioxidant Activity

\begin{tabular}{ccccc}
\hline Concentration $(\mathrm{ppm})$ & Absorbance & \% Inhibition & Regression & IC $_{50}$ \\
\hline 0 & 0.8845 & 0.00 & & \\
4 & 0.7654 & 13.46 & & \\
8 & 0.5873 & 33.60 & $\mathrm{y}=16.2295 \mathrm{x}-0.8672$ & $3.14 \mu \mathrm{g} / \mathrm{ml}$ \\
12 & 0.4470 & 49.47 & & \\
16 & 0.3331 & 62.34 & & \\
20 & 0.1748 & 80.24 & & \\
\hline
\end{tabular}

*Result from triplo sample test ; *Absorbance Control is 0,8845

extract of trengguli bark with DPPH method from several studies were $27.94 \mu \mathrm{g} / \mathrm{mL}^{16}$ and $10.61 \mu \mathrm{g} / \mathrm{mL}^{9}$. In this research, $\mathrm{IC}_{50}$ extract of trengguli bark extract is $10.98 \mu \mathrm{g} / \mathrm{mL}$ (Table 4). The different results of studies above are probably due to differences in conditions and location test and the origin of medicinal plants that affect the content of antioxidant compound.

The combination of both extract (1: 1.5), chosen to illustrate the combination of the minimum dose of the two extracts, shows $\mathrm{IC}_{50}$ values is $13.70 \mu \mathrm{g} / \mathrm{mL}$ (Table 6). The minimum dose that still has antioxidant activity for turmeric rhizome extract is $100 \mathrm{mg} / \mathrm{kg} \mathrm{bw}$ and trengguli bark extract is $150 \mathrm{mg} / \mathrm{kg} \mathrm{bw}^{9}$. From the results of research that $\mathrm{IC}_{50}$ values of ethanol extract of trengguli bark is better than ethanol extract of turmeric rhizome which causes antioxidant activity becomes stronger than single extract of turmeric rhizome, but the combination ethanol extract of turmeric rhizome - trengguli bark (1: 1.5) has not been able to produce $\mathrm{IC}_{50}$ value smaller than ethanol extract of trengguli bark. This is probably due to the comparison between the two extracts based on the minimum dose can not reach the $\mathrm{IC}_{50}$ value under a single extract of the trengguli, but the combination can still prove that with a combination ethanol extract of turmeric rhizome - trengguli bark (1: 1.5) including a very strong antioxidant category.

\section{Conclusion}

The results showed that ascorbic acid, ethanol extract of turmeric rhizome, ethanol extract of trengguli bark and combination of ethanol extract of turmeric rhizome trengguli bark (1:1.5) gave antioxidant activity by DPPH method. Ascorbic acid, as a comparasion, shows $\mathrm{IC}_{50}$ value $3.14 \mu \mathrm{g} /$ $\mathrm{mL}$. While ethanol extract of trengguli bark has the best antioxidant activity with $\mathrm{IC}_{50}$ value $10.98 \mu \mathrm{g} / \mathrm{mL}$ compare to combination of ethanol extract of turmeric rhizome trengguli bark (1:1.5) and ethanol extract of turmeric rhizome with $\mathrm{IC}_{50}$ value is $13.70 \mu \mathrm{g}$ / $\mathrm{mL}$ and $41.95 \mu \mathrm{g} / \mathrm{mL}$, respectively.

\section{References}

1. Lobo V, Patil A, Chandra N. Free Radical, Antioxidant and Functional Food : Impact on Human Health. Pharmacogn Rev Journal. 2010; 4(8) : 118-126.

2. Mbaoji FN, Ezike AC. Nworu CS, Onyeto CA, Nwabunike IA, Okoli IC, Akah 
PA. Antioxidant And Hepatoprotective Potentials Of Stemonocoleus Micranthus Harms (Fabaceae) Stem Bark Extract, Int J Pharm Pharm Sci. 2016; Vol 8, Issue 7, 47-51.

3. Brand-Williams W, Cuvelier ME, \& Berset, C. Use of a free radical method to evaluate antioxidant activity. LWT - Food Science and Technology.1995;28(1), 25-30

4. Widyawati PS. Determination Of Antioxidant Capacity In Pluchea Indica Less Leaves Extract And Its Fractions, Int J Pharm Pharm Sci. 2016; Vol 8, Issue 9, 32-36.

5. Fatima ZAB, Seddik K, Lekhmici A. Antioxidant Activity Assessment Of Tamus Communis L. Roots. Int J Pharm Pharm Sci. 2016; Vol 8, Issue 12, 64-71.

6. Jothy SL, Zuraini Z, Sasidharan S. Phytochemicals screening, DPPH free radical scavenging and xanthine oxidase inhibitiory activities of Cassia fistula seeds extract. Journal of Medicinal Plants Research, 2011; 5(10), 1941-1947.

7. Sengupta M, Sharma GD, Chakraborty B. Hepatoprotective and Immunomodulatory properties of aqueous extract of Curcuma longa in Carbon tetra chloride intoxicated Swiss albino mice. Asian Pacific Jour of Trop Biomed. 2011; 193-199.

8. Tzekiat L, Chiang, LK. Total Phenolics, Total Tannins And Antioxidant Activity Of Cassia fistula L. Extracts Of Bark, Stem, Leaf and Root Under Different Age Classes. Asian Jour Pharm Res \& Health Care. 2013; Vol. 2, Issue 2, 52-57.

9. Najihudin A, Yohana AC, Subarnas A. Aktivitas Antioksidan Ekstrak dan Fraksi Kulit Batang Trengguli (Cassia Fistula L) dengan Metode DPPH. Indonesian Jour. Pharm Sci \& Tech. 2017.
10. Pradeep K, Victor C, Mohan R, Gobianand K, Karthikeyan S. Effect of Cassia fistula Linn. leaf extract on diethylnitrosamine induced hepatic injury in rats. ChemicoBiological Journal. 2007; Vol. 167, Issue 1, 12-18.

11. Ishita C, Kaushik B. Turmeric And Curcumin : Biological Actions And Medical Applications (Review). Current Science Journal. 2004; 87 : 44-50.

12. Kalantari H, Khorsandi LS, Taherimobarakh M. The Protective Effect of The Curcuma longa extract on acetaminophen-induced hepatotoxicity in mice, Jundishapur Jour. of Nat. Pharm. Prod. 2007; 2(1) : 7-12.

13. Hartono, Ida N, Fany I, Wiryanto. Pengaruh Ekstrak Rimpang Kunyit (Curcuma domestica Val.) Terhadap Peningkatan Kadar SGOT Dan SGPT Tikus Putih (Rattus norvegicus) Akibat Pemberian Asetaminofen. Jurnal Biofarmasi. 2005; 3(2): 57-60.

14. Nurcholis W, Laksmi A, Ni LPEKS, Latifah KD. Curcuminoid Contents, Antioxidant and Anti-Inflammatory Activities of Curcuma xanthorrhiza RoxB. and Curcuma domestica Val. Promising Lines From Sukabumi of Indonesia. Prosiding Seminar Nasional Kimia Unesa. 2012 - ISBN : 978-979028-550-7.

15. Nahak G, Sahu RK. Evaluation of antioxidant activity in ethanolic extracts of five curcuma species, Int Research Jour. Pharm. 2011; 2 (12), 243 - 248.

16. Noorhajati H. Aktivitas Antioksidan Ekstrak Kulit Batang Trengguli (Cassia fistula L) dengan uji DPPH, Prosiding Seminar Nasional Sains IX, 2014; Vol 5, No.1. 